\title{
Arbeidstevredenheid als maat voor kwaliteit van de arbeid
}

\author{
Floor Knoop en Roel Schouteten*
}

\begin{abstract}
Door Nederlandse organisaties wordt veel geld besteed aan het meten van de arbeidstevredenheid om de $k$ waliteit van de arbeid en de prestaties van de organisaties te verbeteren. Vanuit de arbeidssociologie en - psychologie wordt regelmatig kritiek geuit op het gebruik van arbeidstevredenheid als maat voor kwaliteit van de arbeid, omdat er sprake zou zijn van aanpassing of dat arbeidstevredenheid te herleiden is tot een persoonlijkheidseigenschap. Echter veelvuldig empirisch onderzoek in Nederland naar de vraag of arbeidstevredenheid een goede maat is voor kwaliteit van de arbeid ontbreekt. Daarom hebben we in Engelstalige literatuur naar argumenten voor het beantwoorden van deze vraag gezocht.

Uit de vijftig bestudeerde onderzoeken komt naar voren dat er vele oorzaken voor arbeidstevredenheid zijn gevonden, waaronder werkkenmerken en persoonlijkheidskenmerken, zoals negatieve affectiviteit. Aanpassing hebben we niet kunnen vinden, omdat geen enkele studie dit fenomeen afdoende in kaart heeft gebracht. In veel bijdragen wordt aanpassing wel als verklaring opgevoerd, maar echt gemeten is dat niet. Omdat werkkenmerken niet de enige oorzaken van arbeidstevredenheid zijn, concluderen wij dat arbeidstevredenheid geen goede maat voor kwaliteit van de arbeid is.
\end{abstract}

Trefwoorden: arbeidstevredenheid, kwaliteit van de arbeid, aanpassing, werkkenmerken, literatuurstudie

\section{Inleiding}

Vele organisaties in Nederland besteden veel energie en geld aan het meten van medewerkertevredenheid om op die manier de kwaliteit van de arbeid en daarmee organisatieprestaties te verbeteren. Er zijn zelfs gespecialiseerde adviesbureaus op dit terrein, zoals Effectory en \&Samhoud, die zich richten op het bevorderen van plezier en tevredenheid om bedrijfsprestaties te verbeteren (zie bijvoorbeeld Geelhoed et al., 2003). Daarbij baseren ze zich op modellen die een positieve relatie veronderstellen tussen medewerkertevredenheid en prestaties, zoals de service-profit chain (Heskett et al., 1994) en de customer-service-profit chain (Rucci et al., 1998). De vraag die dit oproept is of de mate van medewerkertevredenheid (of arbeidstevredenheid) in een organisatie voldoende handvatten voor die organisatie biedt om de kwaliteit van de arbeid te verbeteren met het oog op het verbeteren van prestaties. Met andere woorden: is het meten van arbeidstevredenheid (als subjectief fenomeen) wel een goede maat voor kwaliteit van de arbeid (waar een organisatie op kan sturen)?

Zowel vanuit de arbeidssociologie als -psychologie is er kritiek op het gebruik van arbeidstevredenheid als maat voor kwaliteit van de arbeid. In de Nederlandse arbeidssociologie wordt vaak verwezen naar de arbeidssatisfactieparadox. Volgens De Sitter (1994: 6; Berting \& De Sitter, 1971: 64) laat medewerkerstevredenheidsonderzoek bijna altijd een

* Floor Knoop werkt als accountmanager bij Capac Inhouse Services.

Roel Schouteten is universitair docent bij de Faculteit der Managementwetenschappen, Radboud Universiteit Nijmegen. Correspondentieadres: Radboud Universiteit Nijmegen, Faculteit der Managementwetenschappen, Postbus 9108, 6500 HK Nijmegen. E-mail: r.schouteten@fm.ru.nl. De auteurs bedanken Erik Poutsma voor zijn opmerkingen bij een eerdere versie van deze bijdrage. 
score van 70-80 procent tevreden medewerkers zien, ongeacht de aard van het werk en de omstandigheden waaronder dat verricht moet worden. Daardoor levert onderzoek naar medewerkertevredenheid vooral inzicht op in de mate van aanpassing aan het werk en zegt het niet zozeer iets over de kenmerken van het werk. De conclusie hieruit is dat arbeidstevredenheid als maat voor kwaliteit van de arbeid niet voldoet. Ook vanuit de psychologie is er kritiek op het gebruik van arbeidstevredenheid als maat voor kwaliteit van de arbeid, omdat arbeidstevredenheid kan worden herleid tot een persoonlijkheidseigenschap (bijvoorbeeld Staw \& Ross, 1985) en daardoor meer over de persoon dan over het werk zegt.

Echter, Achterberg, Houtman en Jetten (2003) hebben de aanpassingsthese ontkracht door aan te tonen dat mensen die korter een bepaalde functie vervullen meer tevreden blijken te zijn dan mensen die dezelfde functie al langer vervullen. Ook Vogelaar en van der Vlist (1995) tonen aan dat de aanpassingsthese niet houdbaar bleek in hun onderzoek. Een jaar na een kwaliteitsverbetering van hun werk waren de medewerkers in de verbeterde functies meer tevreden in vergelijking met werknemers in een controlesituatie. Als de aanpassingsthese klopt, zou er na zo'n lange periode geen verschil tussen die groepen meetbaar moeten zijn. De Witte (2001) komt ook tot de conclusie dat arbeidstevredenheid een zinvol concept is en dat het een duidelijke relatie met kwaliteit van de arbeid heeft.

Voor kwaliteit van de arbeid kan er grofweg een onderscheid worden gemaakt tussen een 'objectieve' werkgerelateerde invalshoek en een 'subjectieve' fitbenadering (zie bijvoorbeeld De Witte \& Van Ruysseveldt, 1998). Bij de laatste gaat het om de 'fit' tussen werk en werknemer. De termen objectief en subjectief zijn in dit verband verwarrend (vergelijk Christis, 1998). Daarom geven we de voorkeur aan de termen werkgebonden en fitgebonden. Het verschil tussen beide benaderingen is het al dan niet meenemen van persoonsgebonden oorzaken van kwaliteit van de arbeid in de fitbenadering. Bij beide benaderingen van kwaliteit van de arbeid speelt satisfactie of arbeidstevredenheid een rol als symptoom. In het ene geval is het een symptoom voor de kwaliteit van de werkkenmerken, in het andere geval voor de kwaliteit van afstemming tussen werk- en persoonskenmerken. Omdat persoonskenmerken voor organisaties minder gemakkelijk zijn te veranderen, kiezen wij in deze studie voor de werkgerelateerde definitie van kwaliteit van de arbeid. In aansluiting hierop beschouwen wij arbeidstevredenheid dus als een goede maat voor kwaliteit van de arbeid als het organisaties inzicht verschaft in mogelijkheden om die kwaliteit van de arbeid via werkkenmerken te verbeteren. Als satisfactie te herleiden is tot een persoonlijkheidseigenschap of tot een aanpassingsfenomeen, dan is het in onze ogen niet bruikbaar als maat voor kwaliteit van de arbeid.

Om deze vraag te beantwoorden bespreken we in deze bijdrage een overzicht van Engelstalige empirische studies, omdat er in het Nederlandse taalgebied maar weinig empirische studies zijn die op deze vraag ingaan (uitzonderingen zijn bijvoorbeeld Achterberg et al., 2003 en De Witte, 2001). In de volgende paragraaf bespreken we theoretische inzichten die in de discussie worden gebruikt om aan te geven of arbeidstevredenheid een goede maat voor kwaliteit van de arbeid is. Op basis daarvan formuleren we hypothesen die we met behulp van vijftig empirische studies toetsen. In de daaropvolgende paragraaf geven we aan hoe we die empirische studies hebben geselecteerd en vervolgens wat daarvan de resultaten zijn. Ten slotte schetsen we onze conclusies, zowel voor praktijkonderzoek om kwaliteit van de arbeid te verbeteren, als voor wetenschappelijk onderzoek om de relatie tussen arbeidstevredenheid en kwaliteit van de arbeid nader te duiden.

\section{Voor- en tegenstanders van arbeids- tevredenheid als maat voor kwaliteit van de arbeid}

Arbeidstevredenheid is een van de meest bestudeerde onderwerpen in arbeidspsychologie en -sociologie (Locke, 1976; Judge et al., 2001), en ook in de economische wetenschappen wordt het steeds relevanter geacht /Green 
\& Tsitsianis, 2005). ${ }^{1}$ Er is dan ook een breed palet aan theorieën en inzichten waaruit voor- en tegenstanders putten om te betogen waarom arbeidstevredenheid al dan niet een goede maat voor kwaliteit van de arbeid is.

Tegenstanders beroepen zich met name op de cognitieve dissonantietheorie, PersonEnvironment Fit Theory (P-E Fit), Work Adjustment theorie en Negative Affectivity. De cognitieve dissonantietheorie (Festinger, 1957) gaat uit van de assumptie dat mensen op basis van hun rationaliteit streven naar consistentie in hun gedachtepatroon. Wanneer cognities (het oordeel of de verwachtingen die de persoon heeft over de omgeving) niet corresponderen met de omgeving, is er sprake van dissonantie. In een situatie van dissonantie zal volgens Festinger een persoon zich niet prettig voelen en daarom proberen consonantie te realiseren. Er zijn twee manieren om dissonantie op te lossen: een persoon kan de omgeving veranderen, of zijn cognities bijstellen, zodat cognities en omgeving weer consonant zijn (Festinger, 1957). Toegepast op de werksituatie wordt de cognitieve dissonantietheorie gebruikt om te verklaren waarom medewerkers, ongeacht de werksituatie, toch tevreden zijn, door te wijzen op de aanpassing van de verwachtingen aan de omstandigheden. Indien het niet mogelijk is de werksituatie aan te passen, zal de werknemer zijn verwachtingen met betrekking tot de werkkenmerken aanpassen. Wie bijvoorbeeld werk heeft met weinig mogelijkheden voor zelfontplooiing, zal als reactie daarop minder belang hechten aan dit werkkenmerk (Achterberg et al., 2003). Deze aanpassing van de verwachtingen van de werknemer zorgt ervoor dat werknemers tevreden zijn. Deze redenering hanteert ook De Sitter (1994) om te betogen dat arbeidsvoldoening een aanpassingsfenomeen is.

De redenering van de cognitieve dissonantietheorie over het aanpassen van cognities en verwachtingen aan de omgeving als belangrijke determinant voor arbeidstevredenheid ligt ook ten grondslag aan de P-E Fit Theory (zie bijvoorbeeld Edwards et al., 1998; Taris, 2003) en de Work Adjustment theorie (zie bijvoorbeeld Dawis \& Lofquist, 1978; 1984). De P-E Fit Theory stelt dat gedrag bepaald wordt door interactie tussen kenmerken van de persoon en de kenmerken van de omgeving. Volgens deze theorie zullen werknemers een dergelijke fit proberen na te streven. Een centrale aanname in de theorie is dat de overeenstemming (fit) tussen persoon en zijn werkomgeving (P-E fit) een belangrijke voorspeller is van de uitkomsten in het werk. De meest opmerkelijke uitkomst hierbij is arbeidstevredenheid (Edwards et al., 1998). Dat is ook uit empirisch onderzoek gebleken (Taris, 2003).

Ook de Work Adjustment theorie is gebaseerd op het concept van correspondentie tussen individu en omgeving. Er moet sprake zijn van een harmonieuze of congruente relatie tussen individu en omgeving (Dawis \& Lofquist, 1984). Dit komt ook weer overeen met de redenering in Festinger's cognitieve dissonantietheorie. Zowel de cognitieve dissonantietheorie, P-E Fit Theory als de Work Adjustment theorie verwijzen naar het aanpassingsvermogen van personen om de eigen oordelen en verwachtingen te laten aansluiten op de werkelijke situatie, hetgeen tot tevredenheid leidt. Op basis daarvan is arbeidstevredenheid een aanpassingsfenomeen en dus niet geschikt als maat voor kwaliteit van de arbeid.

Een andere psychologische kritiek op het gebruik van arbeidstevredenheid als maat voor kwaliteit van de arbeid is dat arbeidstevredenheid te herleiden is tot een persoonlijkheidseigenschap, zoals negatieve affectiviteit, locus of control, of self-efficacy. Met name de rol van negatieve affectiviteit (NA) is vaak besproken (Spector et al., 1999). Volgens Burke et al. (1993) heeft NA een grote invloed op tevredenheid. NA is een gevoelsdimensie die individuele verschillen in negatieve emotionaliteit en het zelfconcept weergeeft. Burke et al. laten zien dat uit onderzoek is gebleken dat personen met een hoge NAscore zich meer focussen op de negatieve aspecten die zij in het werk ervaren en vaker negatieve gevoelens ervaren dan personen met een lage NA-score. Tevens is uit onderzoek gebleken dat negatieve affectiviteit gerelateerd is aan werkuitkomsten, zoals arbeidstevredenheid en stress. Het idee is dus dat sommige individuen nu eenmaal positiever zijn ingesteld dan anderen en beter bestand zijn tegen stress. Zij vertonen hierdoor ook meer tevredenheid met betrekking 
tot het werk. Indien dit het geval is, zegt arbeidstevredenheid ons ook niets over het werk, maar wel veel over het karakter van de werknemer die als het ware steeds 'een roze bril' opzet (Staw \& Ross, 1985).

Voorstanders van arbeidstevredenheid als maat voor kwaliteit van de arbeid verwijzen vooral naar het belang van werkkenmerken als determinanten van arbeidstevredenheid. Er zijn veel factoren van invloed op arbeidstevredenheid. Deze zijn in te delen in drie groepen: organisatiekenmerken, werkkenmerken en persoonskenmerken (Furnham, 1992). Uit onderzoek van Arvey et al. (1991) komt naar voren dat 40 tot 60 procent van de variantie in werktevredenheid verklaard wordt door de werkkenmerken, 10 tot 30 procent door persoonskenmerken (zoals negatieve affectiviteit) en 10 tot 20 procent door de interactie (fit) tussen situatie en persoon. Gezien deze cijfers verwerpen zij de kritieken van de onderzoekers die op basis van de aanpassingsthese, arbeidstevredenheid geen goede maat voor kwaliteit van de arbeid vinden. Ook de kritiek dat arbeidstevredenheid een persoonlijkheidseigenschap zou zijn, weerleggen zij op basis van deze cijfers. De theoretische basis voor het belang van de werkkenmerken ligt in de werkkenmerkenbenadering waarvan het Job Characteristics Model (JCM; Hackman \& Oldham, 1976) en het Job Demands - Decision Latitude Model (Karasek, 1979) de belangrijkste en meest invloedrijke exponenten zijn. Daarbij verloopt de relatie tussen werkkenmerken en tevredenheid in het JCM via zogenoemde 'critical psychological states'. Karasek daarentegen legt een directe relatie tussen werkkenmerken (balans tussen job demands en decision latitude) en arbeidstevredenheid. Op basis van zijn empirische toetsing geeft Karasek aan dat er een sterk, lineair verband is tussen de beide dimensies in zijn model en de arbeidstevredenheid. Daarnaast laat hij zien dat ook andere gevolgen van het werk voor de werknemer en zelfs werknemersgedrag (absentie) met zijn model voorspeld kunnen worden (Karasek, 1979).

Op basis van de beschreven theoretische inzichten kunnen we de volgende drie hypothesen formuleren aangaande het nut van arbeidstevredenheid als maat voor kwaliteit van de arbeid.

1 Indien de verwachtingen van de persoon en de kenmerken van het werk niet overeenstemmen (er is sprake van dissonantie), zal dit leiden tot aanpassing van de verwachtingen en daarmee tot arbeidstevredenheid. Daarom is arbeidstevredenheid geen goede maat voor kwaliteit van de arbeid.

2 Arbeidstevredenheid wordt bepaald door de werkkenmerken en is daarom wel een goede maat voor kwaliteit van de arbeid.

3 Negatieve affectiviteit beïnvloedt de mate van arbeidstevredenheid, die daarmee geen goede maat voor kwaliteit van de arbeid is.

\section{Methode}

Deze hypothesen willen we toetsen aan de hand van een literatuurstudie van (recente) Engelstalige empirische studies om op basis van meer empirische argumenten conclusies te kunnen trekken over het nut van het meten van arbeidstevredenheid als maat voor kwaliteit van de arbeid. We zijn dus op zoek gegaan naar wetenschappelijke publicaties waarin een of meer van bovenstaande relaties tussen werk en/of persoon en arbeidstevredenheid worden getoetst. Hiertoe hebben we richtlijnen van Lipsey \& Wilson (2001) gevolgd en verschillende zoekstrategieën gebruikt om de 'selection bias' te beperken. In de eerste plaats hebben we in de databestanden van ISI Web of Science, PiCarta en OnLine Contents, met behulp van trefwoorden gezocht naar geschikte bijdragen. Daarbij hebben we de volgende trefwoorden uit de hypothesen gebruikt: Expectancy, Values, Job Characteristics en Job Satisfaction. Tevens hebben we gezocht met de termen: Cognitive Dissonance in combinatie met Work, en Work Adjustment Theory of P-E fit in relatie met Job Satisfaction. In de tweede plaats hebben we gezocht aan de hand van verwijzingen uit overzichtsartikelen en uit de reeds gevonden artikelen. Deze zoektocht leverde een voldoende aantal artikelen op waarin een relatie werd gelegd tussen verwachtingen, werkkenmerken en tevredenheid, of direct tussen werkkenmerken en tevredenheid.

Ten slotte hebben we uit alle verzamelde artikelen een selectie gemaakt op basis van 
bruikbaarheid. Hierbij hebben we de volgende vraag als sluiscriterium gehanteerd: sluiten de definities van de begrippen in het artikel aan bij de definities die we voor dit onderzoek hanteren? Een dergelijke selectie komt de validiteit ten goede, immers alle informatie die niet aansluit bij de relaties en de definities uit het conceptueel model wordt buiten beschouwing gelaten.

Hoewel er voor een literatuurstudie geen minimumaantal studies vereist wordt (zie bijvoorbeeld Iaffaldano \& Muchinsky, 1985), hebben wij in dit onderzoek gekozen voor een minimumaantal van vijftig studies waarmee we de hypothesen willen toetsen. Deze studies hebben we gerangschikt naar welke relaties er worden getoetst. In de volgende paragraaf beschrijven we de resultaten van deze vergelijking.

\section{Resultaten}

In de tabellen 1 tot en met 3 geven we een overzicht van de gevonden studies en de belangrijkste bevindingen. In deze tabellen zijn de studies opgenomen waarmee we respectievelijk de eerste (tabel 1), tweede (tabel 2) en de derde hypothese (tabel 3) kunnen toetsen. Sommige studies hebben we in twee tabellen opgenomen, omdat ze informatie over twee hypothesen verschaffen. We hebben echter geen studies gevonden die informatie verschaffen ten behoeve van het toetsen van alle drie de hypotheses tegelijk. Er zijn dus geen studies verricht waarin zowel werkkenmerken, fitkenmerken (aanpassing) als negatieve affectiviteit als determinanten van arbeidstevredenheid zijn getoetst. Ook hebben we maar weinig studies gevonden waarin uitspraken staan over het nut van het meten van arbeidstevredenheid als maat voor kwaliteit van de arbeid. We zullen dus de resultaten en argumenten van de gevonden studies interpreteren in termen van de hypotheses zoals we die hebben geformuleerd.

Grofweg kunnen we de gevonden studies in twee groepen verdelen. In de eerste groep zitten de studies waarin voornamelijk de relatie is onderzocht tussen de fit (tussen werk en persoon) en arbeidstevredenheid, en de rol van aanpassing in die relatie (hypothese 1). In de tweede groep zitten de studies die de directe relatie tussen werkkenmerken en arbeidstevredenheid hebben onderzocht (hypothese 2). In beide groepen zitten ook studies waarin NA, al dan niet als controlevariabele, is meegenomen (hypothese 3).

Tabel 1 Overzicht van de empirische studies over de relatie tussen de afstemming tussen werk en persoon, aanpassing en arbeidstevredenheid

\begin{tabular}{|c|c|c|c|c|}
\hline Onderzoek & Bevindingen & Citatie* & $\begin{array}{l}\text { Relatie } \\
\text { Fit - AT? }\end{array}$ & $\begin{array}{l}\text { Aanpas- } \\
\text { sing? }\end{array}$ \\
\hline $\begin{array}{l}\text { O'Reilly, } \\
\text { Chatman \& } \\
\text { Caldwel (1991) }\end{array}$ & $\begin{array}{l}\text { Uit longitudinaal onderzoek blijkt fit een significante } \\
\text { voorspeller van arbeidstevredenheid. Werknemers die niet } \\
\text { zeer tevreden of ontevreden zijn zullen zich bij het meten } \\
\text { met een vragenlijst vaak schikken. Daardoor vallen tevreden- } \\
\text { heidsscores vaak hoger uit dan daadwerkelijk het geval is }\end{array}$ & $290 x$ & ja & ja \\
\hline $\begin{array}{l}\text { Kalleberg } \\
(1977)\end{array}$ & $\begin{array}{l}\text { Verschillen tussen mensen in de mate van arbeidstevreden- } \\
\text { heid worden verklaard aan de hand van verschillen in } \\
\text { verwachtingen en percepties. Vooral de waargenomen } \\
\text { werkkenmerken zijn van belang, maar ook arbeidsmarkt, } \\
\text { economische en sociale factoren zijn van invloed }\end{array}$ & $206 x$ & nvt & nvt \\
\hline $\begin{array}{l}\text { Meglino, } \\
\text { Ravlin \& } \\
\text { Adkins (1989) }\end{array}$ & $\begin{array}{l}\text { Ook voor productiemedewerkers geldt dat er in de relatie } \\
\text { tussen fit en arbeidstevredenheid waarschijnlijk sprake is } \\
\text { van aanpassing }\end{array}$ & $136 x$ & ja & $\begin{array}{l}\text { waar- } \\
\text { schijnlijk }\end{array}$ \\
\hline $\begin{array}{l}\text { Hulin \& Smith } \\
\text { (1965) }\end{array}$ & $\begin{array}{l}\text { Er is een relatie tussen fit en arbeidstevredenheid en daarbinnen } \\
\text { is er sprake van aanpassing van wensen aan werkkenmerken }\end{array}$ & $120 x$ & ja & ja \\
\hline
\end{tabular}


Arbeidstevredenheid als maat voor kwaliteit van de arbeid

\begin{tabular}{|c|c|c|c|c|}
\hline Onderzoek & Bevindingen & Citatie* & $\begin{array}{l}\text { Relatie } \\
\text { Fit - AT? }\end{array}$ & $\begin{array}{l}\text { Aanpas- } \\
\text { sing? }\end{array}$ \\
\hline $\begin{array}{l}\text { Kalleberg \& } \\
\text { Loscocco } \\
(1983)\end{array}$ & $\begin{array}{l}\text { Er zijn verschillen tussen ouderen en jongeren in de mate van } \\
\text { aanpassing die tot uiting komt in de mate van arbeids- } \\
\text { tevredenheid }\end{array}$ & $91 \times$ & ja & ja \\
\hline $\begin{array}{l}\text { Cable \& Judge } \\
\text { (1996) }\end{array}$ & $\begin{array}{l}\text { Arbeidstevredenheid wordt bepaald door de mate van fit } \\
\text { tussen wensen en werkkenmerken. Daarbij is sprake van } \\
\text { aanpassing van wensen }\end{array}$ & $86 x$ & ja & ja \\
\hline $\begin{array}{l}\text { Wright \& } \\
\text { Hamilton } \\
\text { (1978) }\end{array}$ & $\begin{array}{l}\text { Als de werksituatie niet aan de verwachtingen tegemoet- } \\
\text { komt, passen medewerkers de verwachtingen aan }\end{array}$ & $67 x$ & ja & ja \\
\hline $\begin{array}{l}\text { Bretz \& Judge } \\
\text { (1994) }\end{array}$ & $\begin{array}{l}\text { Er is een sterke relatie tussen P-E fit en arbeidstevredenheid. } \\
\text { Een misfit leidt tot aanpassing }\end{array}$ & $57 x$ & ja & ja \\
\hline $\begin{array}{l}\text { Rice, Bennet } \\
\& \text { McFarlin } \\
(1989)\end{array}$ & $\begin{array}{l}\text { De mate van fit is zeer bepalend voor de mate van arbeids- } \\
\text { tevredenheid. Discrepantie leidt tot dissatisfactie, maar of } \\
\text { het ook tot aanpassing leidt wordt niet bevestigd }\end{array}$ & $53 x$ & ja & onzeker \\
\hline $\begin{array}{l}\text { Clark, Oswald } \\
\& \text { Warr } \\
(1996)\end{array}$ & $\begin{array}{l}\text { Ouderen en nieuwkomers op de arbeidsmarkt zijn meer } \\
\text { tevreden omdat deze hun verwachtingen bijstellen. } \\
\text { Ook NA is van invloed op de arbeidstevredenheid }\end{array}$ & $46 x$ & ja & ja \\
\hline $\begin{array}{l}\text { Janson \& } \\
\text { Martin (1982) }\end{array}$ & $\begin{array}{l}\text { Ongeacht leeftijd passen werknemers hun verwachtingen } \\
\text { aan om tot arbeidstevredenheid te komen }\end{array}$ & $46 x$ & ja & ja \\
\hline $\begin{array}{l}\text { George \& } \\
\text { Jones (1996) }\end{array}$ & $\begin{array}{l}\text { Ervaringen in het werk worden door vele facetten bepaald. } \\
\text { Verloopintentie wordt in deze studie verklaard door (interacties } \\
\text { tussen) arbeidstevredenheid, gemoedstoestand en de mate } \\
\text { waarin persoonlijke doelen worden bereikt. Hierbij hangt } \\
\text { positieve affectiviteit (omgekeerde van NA) significant positief } \\
\text { samen met arbeidstevredenheid }\end{array}$ & $39 x$ & ja & nvt \\
\hline $\begin{array}{l}\text { Weiss, } \\
\text { Nicholas \& } \\
\text { Daus (1999) }\end{array}$ & $\begin{array}{l}\text { Naast de beleving van de werksituatie (fit) is iemands gemoeds- } \\
\text { toestand van invloed op arbeidstevredenheid. lemands gemoeds- } \\
\text { toestand wordt op zijn beurt beïnvloed door de mate van } \\
\text { positieve en negatieve affectiviteit }\end{array}$ & $37 x$ & ja & nvt \\
\hline $\begin{array}{l}\text { Rhodes \& } \\
\text { Doering (1983) }\end{array}$ & $\begin{array}{l}\text { Er is sprake van aanpassing, maar deze is afhankelijk van } \\
\text { factoren als leeftijd, financiële status en arbeidsmarktpositie }\end{array}$ & $35 x$ & ja & ja \\
\hline $\begin{array}{l}\text { Gottfredson \& } \\
\text { Holland (1990) }\end{array}$ & $\begin{array}{l}\text { Mensen blijven tevreden over het werk als er voldoende fit is. } \\
\text { Aanpassing wordt niet besproken }\end{array}$ & $29 x$ & ja & nvt \\
\hline $\begin{array}{l}\text { Staines \& } \\
\text { Quinn (1979) }\end{array}$ & $\begin{array}{l}\text { Uit deze trendstudie naar arbeidstevredenheid blijkt dat er } \\
\text { verschillende trends voor verschillende demografische groepen } \\
\text { zijn waar te nemen. De auteurs speculeren over mogelijke } \\
\text { oorzaken, maar de data laten geen definitieve uitspraken over } \\
\text { fit en aanpassing toe }\end{array}$ & $29 x$ & mogelijk & mogelijk \\
\hline $\begin{array}{l}\text { Edwards \& } \\
\text { Rothbard } \\
(1999)\end{array}$ & $\begin{array}{l}\text { Een overeenkomst tussen cognities en werksituatie is zeer } \\
\text { belangrijk voor de arbeidstevredenheid. Een gebrek aan overeen- } \\
\text { komst leidt tot stress. Over aanpassing doen ze geen uitspraken }\end{array}$ & $26 x$ & ja & nvt \\
\hline $\begin{array}{l}\text { Hesketh \& } \\
\text { Gardner (1993) }\end{array}$ & $\begin{array}{l}\text { P-E fit bepaalt de mate van arbeidstevredenheid. Bij een misfit } \\
\text { resulteert dit in ontevredenheid. Over aanpassing wordt niet } \\
\text { gesproken }\end{array}$ & $26 x$ & ja & nvt \\
\hline
\end{tabular}




\begin{tabular}{|c|c|c|c|c|}
\hline Onderzoek & Bevindingen & Citatie* & $\begin{array}{l}\text { Relatie } \\
\text { Fit - AT? }\end{array}$ & $\begin{array}{l}\text { Aanpas- } \\
\text { sing? }\end{array}$ \\
\hline $\begin{array}{l}\text { Boxx, Odom \& } \\
\text { Dunn (1991) }\end{array}$ & $\begin{array}{l}\text { De fit tussen wensen/verwachtingen en de werkkenmerken } \\
\text { heeft een relatie met arbeidstevredenheid, maar aanpassing is } \\
\text { niet waargenomen }\end{array}$ & $15 x$ & ja & nee \\
\hline $\begin{array}{l}\text { Black \& Ashford } \\
\text { (1995) }\end{array}$ & $\begin{array}{l}\text { Werknemers passen zich gedeeltelijk aan, maar proberen ook } \\
\text { zo veel mogelijk te bereiken dat de werksituatie tegemoetkomt } \\
\text { aan de verwachtingen }\end{array}$ & $13 x$ & nvt & $\begin{array}{l}\text { gedeel- } \\
\text { telijk }\end{array}$ \\
\hline $\begin{array}{l}\text { Lauver \& } \\
\text { Kristof-Brown } \\
(2001)\end{array}$ & $\begin{array}{l}\text { In de relatie tussen fit en arbeidstevredenheid is er sprake van } \\
\text { aanpassing van verwachtingen }\end{array}$ & $13 x$ & ja & ja \\
\hline $\begin{array}{l}\text { Saks \& Ashford } \\
(2002)\end{array}$ & $\begin{array}{l}\text { Dit longitudinaal onderzoek onder } 113 \text { afgestudeerden naar } \\
\text { werkzoekgedrag, fitbeleving en kwaliteit van de arbeid laat een } \\
\text { duidelijk verband zien tussen de mate van Person-Job fit en } \\
\text { verloopintentie en arbeidstevredenheid }\end{array}$ & $13 x$ & ja & nvt \\
\hline $\begin{array}{l}\text { Buckley, Fedor, } \\
\text { Veres, Weise \& } \\
\text { Carraher (1998) }\end{array}$ & $\begin{array}{l}\text { Bij nieuwkomers op de arbeidsmarkt is er een relatie tussen fit } \\
\text { en arbeidstevredenheid. Maar aanpassing is niet waargenomen }\end{array}$ & $12 x$ & ja & nee \\
\hline $\begin{array}{l}\text { Ilardi, Leone, } \\
\text { Kasser \& Ryan } \\
\text { (1993) }\end{array}$ & $\begin{array}{l}\text { Er is een relatie tussen verwachtingen en arbeidstevredenheid, } \\
\text { en bij discrepantie tussen verwachtingen en werkkenmerken } \\
\text { zullen de verwachtingen worden aangepast. Daarnaast blijkt NA } \\
\text { van invloed te zijn op arbeidstevredenheid }\end{array}$ & $11 \times$ & ja & ja \\
\hline $\begin{array}{l}\text { Semmer \& } \\
\text { Schallberger } \\
(1996)\end{array}$ & $\begin{array}{l}\text { Tot op zekere hoogte kan er sprake zijn van aanpassing, maar } \\
\text { een te grote mate van dissonantie zal tot ontevredenheid en } \\
\text { verloop leiden }\end{array}$ & $10 \times$ & ja & ja \\
\hline Hinrichs (1972) & $\begin{array}{l}\text { Er is sprake van aanpassing, maar ook de persoonskenmerken } \\
\text { NA en depressie zijn van invloed op arbeidstevredenheid }\end{array}$ & $7 \times$ & ja & ja \\
\hline $\begin{array}{l}\text { Büssing, Bissels, } \\
\text { Fuchs \& Perrar } \\
\text { (1999) }\end{array}$ & $\begin{array}{l}\text { Bij een goede fit tussen cognities en werk zijn werknemers } \\
\text { tevreden. Bij een misfit zal de werknemer ofwel het werk, ofwel } \\
\text { de verwachtingen aanpassen }\end{array}$ & $1 \times$ & ja & ja \\
\hline Eggerth (2004) & $\begin{array}{l}\text { Het is mogelijk dat medewerkers met een ambivalente arbeids- } \\
\text { tevredenheidsscore hun wensen hebben aangepast. Het gebruik } \\
\text { van arbeidstevredenheid als maat is daarom omstreden }\end{array}$ & $0 \times$ & ja & mogelijk \\
\hline
\end{tabular}

\footnotetext{
* Het aantal citaties is het aantal keren dat de bijdrage is geciteerd in in de Social Sciences Citation Index opgenomen tijdschriften (bepaald op 19-2-06).
}

Afstemming tussen werk en persoon, aanpassing en arbeidstevredenheid

We hebben 28 studies gevonden over de relatie tussen de afstemming tussen werk en persoon (P-E fit) en arbeidstevredenheid. In 21 van deze studies worden uitspraken gedaan over aanpassingsgedrag. Ook zijn er onderzoekers die naast P-E fit en aanpassingsvariabelen nog specifieke persoons- en/of contextgebonden factoren in het onderzoek hebben meegenomen (onder andere Wright \& Hamilton, 1978; Ilardi et al., 1993; Rhodes \& Doering, 1983).
De onderzoeksresultaten uit deze studies laten zien dat er sprake is van een sterke relatie tussen de P-E fit en arbeidstevredenheid; hoe beter de fit, hoe meer arbeidstevredenheid. Daarbij wordt vaak vermeld dat bij het ontbreken van een afstemming tussen de werkkenmerken en de verwachtingen, dit zal leiden tot aanpassing van de verwachtingen (Bretz \& Judge, 1994; Kalleberg, 1977; Lauver \& Kristof-Brown, 2001; Cable \& Judge, 1997). Büssing et al. (1999) onderscheiden hiervoor zelfs een aparte vorm van arbeidstevreden- 
heid, namelijk 'redesigned jobsatisfaction'. In het meest geciteerde (en daarom invloedrijke) onderzoek in tabel 1 baseren O'Reilly et al., (1991) zich op de Work Adjustmenttheorie van Dawis \& Lofquist (1984). Ze benadrukken het belang van de congruentie tussen de wensen/verwachtingen van de persoon en de werkkenmerken. Zij verrichtten longitudinaal onderzoek onder MBA-studenten. De resultaten laten zien dat de mate van fit een significante voorspeller is van de arbeidstevredenheid (de regressiecoëfficiënt is .36, $\mathrm{p}<.01)$. Met betrekking tot aanpassing vermelden zij dat werknemers die niet zeer tevreden of ontevreden zijn zich vaak zullen schikken bij het meten met een vragenlijst. Daardoor vallen tevredenheidsscores vaak hoger uit dan daadwerkelijk het geval is.

In een ander vaak geciteerd onderzoek, van Kalleberg (1977), wordt de relatie tussen de wensen met betrekking tot het werk en de waargenomen werkkenmerken en arbeidstevredenheid gemeten. Kalleberg heeft onderzoek verricht onder 1496 werkenden in de Verenigde Staten en Colombia door middel van persoonlijke interviews. De resultaten laten zien dat er een relatief hoge correlatie is tussen de wensen met betrekking tot het werk, de waargenomen werkkenmerken en arbeidstevredenheid. De waargenomen werkkenmerken laten een hoge correlatie zien met arbeidstevredenheid, daartegenover is de correlatie tussen de verwachtingen en de arbeidstevredenheid bijna 0 . Bepalend voor het feit of de medewerker zich bij discrepantie toch tevreden zal stellen met de waargenomen werkkenmerken zijn, volgens Kalleberg (1977) hoe lang de werknemer al werkzaam is, de mate waarin hij bijgeschoold is, het ras van de werknemer, en vakbondslidmaatschap. Indien men minder kansen heeft op de arbeidsmarkt, zal men zich sneller tevreden stellen en minder snel vertrekken.

Rhodes \& Doering (1983) komen tot een vergelijkbare conclusie. Ook zij benadrukken dat het belangrijk is voor de arbeidstevredenheid dat er sprake is van een beleefde fit tussen de wensen of verwachtingen van een persoon en de kenmerken van het werk. Of ontevreden werknemers, die geen fit ervaren tussen hun wensen en de kenmerken van het werk, hun wensen bijstellen om toch tot een fit te komen, hangt volgens Rhodes \& Doering af van verschillende factoren. Als voorbeeld noemen zij leeftijd, financiële status en arbeidsmarktcondities. Deze factoren zijn bepalend voor eventuele andere (betere) opties.

Uit tabel 1 blijkt ook dat er onderzoeken zijn die een relatie leggen tussen de mate van P-E fit en de arbeidstevredenheid, maar die niet zo duidelijk pleiten voor aanpassing. Dit zijn onder andere de onderzoeken van Meglino et al. (1989), Rice et al. (1989), Boxx et al. (1991), Black \& Ashford (1995) en Eggerth (2004).

Rice et al. (1989) onderzochten de discrepantietheorie door middel van vragenlijsten onder 78 werknemers. Eerst wordt de discrepantie gemeten met betrekking tot de verschillende werkkenmerken. Vervolgens wordt ook door middel van een vragenlijst de arbeidstevredenheid gemeten. Opvallend is dat zij zich specifiek richten op de arbeidstevredenheid ten aanzien van verschillende werkkenmerken (bijvoorbeeld, het salaris, de mate van klantcontact, promotiekansen). Als de discrepantiescores in verband gebracht worden met de tevredenheidsscores ten aanzien van de gemeten werkkenmerken, blijkt de regressiecoëfficiënt voor elk werkkenmerk negatief. Over het algemeen geldt dus: hoe kleiner de discrepantie, hoe groter de tevredenheid. Rice et al. komen dan ook tot de conclusie dat discrepantie tussen verwachtingen en de werkkenmerken een sleutelrol spelen in het voorspellen van de arbeidstevredenheid. Over de wijze waarop deze discrepantie verkleind wordt, doen zij geen uitspraak.

Het onderzoek van Eggerth (2004), dat werd uitgevoerd door middel van twee vragenlijsten onder 71 verpleegkundigen, om de wensen en de tevredenheid te meten, bevestigt deze gedachte.

De wensen met betrekking tot het werk werden gemeten met de Minnesota Job Importance Questionnaire. Hierin werd individuen gevraagd een waarde toe te kennen aan twintig werkkenmerken. De tevredenheid is gemeten met de Minnesota Satisfaction Questionnaire. Hierin wordt men verzocht op een vijfpuntsschaal aan te geven hoe tevreden men is over de twintig werkkenmerken. De resultaten van de uitgevoerde studie zijn volgens Eggerth (2004) in overeenstemming met de Work Adjustment Theory. Zoals voorspeld zijn alle verpleegkundigen tevreden genoeg 
om in de organisatie te blijven werken. 24 procent van alle ondervraagden is zeer duidelijk tevreden. De overige 76 procent heeft een score die te plaatsen is tussen matig tevreden en matig ontevreden. De meerderheid van de ondervraagde verpleegkundigen kan volgens Eggerth als ambivalent gekarakteriseerd worden. Zij hebben zich min of meer weten te schikken naar de daadwerkelijke situatie.

Meglino et al. (1989) en Ilardi et al. (1993) hebben bewust voor een andere werkcontext gekozen, namelijk een productiesetting. Ook uit deze onderzoeken komt naar voren dat er een sterke relatie is tussen de mate waarin het werk tegemoetkomt aan de verwachtingen en de mate van arbeidstevredenheid. Zij geven echter aan dat dit geen reden is om aanpassing te veronderstellen, omdat voor dergelijke conclusies longitudinaal onderzoek noodzakelijk is.

Longitudinaal onderzoek is wel verricht door Saks \& Ashforth (2002), maar zij hebben aanpassing niet direct gemeten. Zij onderzochten de relatie tussen P-E fit en de arbeidstevredenheid onder afgestudeerden van een universiteit. Uit de resultaten blijkt dat de mate van fit zeer bepalend is voor de arbeidstevredenheid. Opvallend is dat zij een verschil meten in de perceptie van de mate van fit tussen een starter en iemand die al langer werkzaam is in een bepaalde functie.

Geen van de hier besproken studies, waarin een relatie tussen aanpassing en arbeidstevredenheid wordt gelegd, legt nadrukkelijk, zoals De Sitter (1994), de relatie tussen deze resultaten en de vraag of arbeidstevredenheid een goede maat is voor kwaliteit van de arbeid. De oorzaak daarvan is dat de studies primair waren gericht op de relatie tussen P-E fit en het fenomeen arbeidstevredenheid (en niet zozeer op de vraag of arbeidstevredenheid wel een goede maat is voor wat dan ook). Aanpassing van wensen en verwachtingen wordt in deze studies vooral gebruikt als een verklaring voor de gevonden relaties. Geen enkele studie, ook niet de longitudinale studie van Saks \& Ashford (2002), heeft aanpassing als fenomeen gemeten. Een verklaring hiervoor is dat aanpassing als variabele nauwelijks is geoperationaliseerd (Lawson, 1993). Omdat aanpassing niet is gemeten en hooguit als verklaring wordt geopperd, kunnen we op basis van deze studies de eerste hypothese aangaande aanpassing niet aannemen of verwerpen.

Tabel 2 Overzicht van de empirische studies over de relatie tussen werkkenmerken en arbeidstevredenheid

\begin{tabular}{|c|c|c|c|c|}
\hline Onderzoek & Bevindingen & Citatie* & $\begin{array}{l}\text { Relatie } \\
\text { werk - } \\
\text { AT? }\end{array}$ & $\begin{array}{l}\text { Invloed } \\
\text { persoons- } \\
\text { kenmerken? }\end{array}$ \\
\hline $\begin{array}{l}\text { Kalleberg } \\
\text { (1977) }\end{array}$ & $\begin{array}{l}\text { Verschillen tussen mensen in de mate van arbeidstevreden- } \\
\text { heid worden verklaard aan de hand van verschillen in } \\
\text { verwachtingen en percepties. Vooral de waargenomen } \\
\text { werkkenmerken zijn van belang, maar ook arbeidsmarkt, } \\
\text { economische en sociale factoren zijn van invloed }\end{array}$ & $206 x$ & ja & ja \\
\hline Warr (1990) & $\begin{array}{l}\text { Arbeidstevredenheid hangt samen met affectieve gezond- } \\
\text { heidsgevoelens die het gevolg zijn van werkkenmerken. } \\
\text { Maar ook leeftijd, geslacht en werkniveau zijn hierop } \\
\text { van invloed }\end{array}$ & $146 x$ & indirect & ja \\
\hline $\begin{array}{l}\text { Landsbergis } \\
\text { (1988) }\end{array}$ & $\begin{array}{l}\text { Werkkenmerken (van Karasek) zijn van invloed op } \\
\text { arbeidsontevredenheid, zelfs bij controle voor een groot } \\
\text { aantal demografische variabelen }\end{array}$ & $132 \times$ & ja & nee \\
\hline $\begin{array}{l}\text { Glisson \& } \\
\text { Durick (1988) }\end{array}$ & $\begin{array}{l}\text { Taakkenmerken en niet persoonskenmerken, bepalen de } \\
\text { arbeidstevredenheid }\end{array}$ & $113 \times$ & ja & nee \\
\hline $\begin{array}{l}\text { Fox, Dwyer \& } \\
\text { Ganster (1993) }\end{array}$ & $\begin{array}{l}\text { Ondersteuning voor het Karasek-model. } \\
\text { Arbeidstevredenheid is een goede maat voor kwaliteit } \\
\text { van de arbeid }\end{array}$ & $101 \times$ & ja & nvt \\
\hline
\end{tabular}


Arbeidstevredenheid als maat voor kwaliteit van de arbeid

\begin{tabular}{lllll}
\hline Onderzoek & Bevindingen & Citatie* & $\begin{array}{l}\text { Relatie } \\
\text { werk }-\begin{array}{l}\text { Invloed } \\
\text { persoons- } \\
\text { AT? }\end{array}\end{array}$ & zenmerken \\
\hline $\begin{array}{l}\text { Spector (1987) } \\
\begin{array}{l}\text { Er is een zwakke relatie tussen werkkenmerken en } \\
\text { arbeidstevredenheid. De relatie tussen NA en arbeids- } \\
\text { tevredenheid is veel sterker }\end{array}\end{array}$ & $88 \times$ & ja \\
\hline
\end{tabular}

\begin{tabular}{|c|c|c|c|}
\hline $\begin{array}{l}\text { Payne \& } \\
\text { Fletcher (1983) }\end{array}$ & $\begin{array}{l}\text { Er is een zwakke relatie tussen werkkenmerken en arbeids- 86x } \\
\text { tevredenheid. Daarom moet arbeidstevredenheid veel } \\
\text { meer te maken hebben met persoonlijkheidskenmerken, } \\
\text { zoals NA, en andere omgevingskenmerken buiten het } \\
\text { werk. Maar deze zaken zijn in dit onderzoek niet gemeten }\end{array}$ & zwak & $\begin{array}{l}\text { niet } \\
\text { gemeten }\end{array}$ \\
\hline
\end{tabular}

\begin{tabular}{lllll}
\hline Tetrick \& & Vooral de mate van controle is belangrijk voor de arbeids- & 86x & ja & nvt \\
LaRocco & tevredenheid. Deze kan zelfs als 'tegengif' dienen voor & & & \\
(1987) & werkgerelateerde stress & &
\end{tabular}

Wall, Jackson, De taakkenmerken uit het Karasek-model bepalen de
Mullar \& Parker arbeidstevredenheid
(1996)

\begin{tabular}{llccc}
\hline $\begin{array}{l}\text { Spector \& } \\
\text { O'Connel (1994) } \begin{array}{l}\text { Zowel werkenmerken als persoonlijkheidskenmerken } \\
\text { correlen met arbeidstevredenheid }\end{array}\end{array}$ & $84 \times$ & ja & ja \\
\hline $\begin{array}{l}\text { Dwyer \& } \\
\text { Ganster (1991) }\end{array}$ & $\begin{array}{l}\text { Zowel demands als control zijn goede voorspellers van } \\
\text { arbeidstevredenheid }\end{array}$ & $81 \times$ & ja & nvt \\
\hline $\begin{array}{l}\text { Necowitz \& } \\
\begin{array}{l}\text { Roznowski } \\
(1994)\end{array}\end{array} \quad \begin{array}{l}\text { Werkkenmerken zijn bepalend voor de mate van arbeids- } \\
\text { tevredenheid, maar persoonskenmerken, waaronder NA, } \\
\text { zijn nog veel belangrijker }\end{array}$ & ja & ja \\
\hline
\end{tabular}

Fletcher \& Jones (1993)

Werkkenmerken verklaren in beperkte mate arbeidstevredenheid. Persoonskenmerken als NA en locus of control worden als verklaring genoemd, maar zijn niet gemeten 48x beperkt ja

$45 \times \quad$ ja nvt

Garland, Oyabu Taakkenmerken bepalen de arbeidstevredenheid. \& Gipson (1989) Daarnaast is ook de sociale context van belang

Griffin (1991) Uit longitudinaal onderzoek naar de relatie tussen functie- $42 \times$ verandering, werkbeleving, betrokkenheid en arbeidstevredenheid blijkt dat na een functieverbetering de arbeidstevredenheid in eerste instantie snel toeneemt, maar na verloop van tijd naar het oude niveau zakt

\begin{tabular}{|c|c|c|c|c|}
\hline Xie (1996) & $\begin{array}{l}\text { Ook onderzoek in een Chinese (niet-westerse) context } \\
\text { ondersteunt het Karasek-model dat van invloed is op } \\
\text { arbeidstevredenheid. Een kanttekening is dat er wel } \\
\text { rekening moet worden gehouden met individuele en } \\
\text { socio-economische verschillen }\end{array}$ & $27 x$ & ja & ja \\
\hline $\begin{array}{l}\text { Sargent \& Terry } \\
\text { (1998) }\end{array}$ & $\begin{array}{l}\text { Ook in de relatie tussen het Karasek-model en arbeids- } \\
\text { tevredenheid is er sprake van aanpassing: iemand met } \\
\text { een hoge mate van controle zal makkelijker zijn wensen } \\
\text { bijstellen, hetgeen tot tevredenheid leidt }\end{array}$ & $22 x$ & ja & nvt \\
\hline $\begin{array}{l}\text { Parkes \& Von } \\
\text { Rabenau (1993) }\end{array}$ & $\begin{array}{l}\text { Ondersteuning voor het Karasek-model: hoge demands } \\
\text { en lage control leiden tot dissatisfactie. Maar daarnaast } \\
\text { heeft ook NA invloed op de arbeidstevredenheid }\end{array}$ & $20 x$ & ja & ja \\
\hline
\end{tabular}




\begin{tabular}{|c|c|c|c|c|}
\hline Onderzoek & Bevindingen & Citatie* & $\begin{array}{l}\text { Relatie } \\
\text { werk - } \\
\text { AT? }\end{array}$ & $\begin{array}{l}\text { Invloed } \\
\text { persoons- } \\
\text { kenmerken? }\end{array}$ \\
\hline $\begin{array}{l}\text { Baba \& Jamal } \\
(1991)\end{array}$ & $\begin{array}{l}\text { Er is sprake van een positieve relatie tussen taakkenmerken } \\
\text { en arbeidssatisfactie }\end{array}$ & $13 x$ & ja & nvt \\
\hline $\begin{array}{l}\text { Saks \& Ashford } \\
(2000)\end{array}$ & $\begin{array}{l}\text { In longitudinaal onderzoek komt naar voren dat de } \\
\text { situationele factoren (werkkenmerken) een significante } \\
\text { invloed hebben op arbeidstevredenheid. De persoonlijk- } \\
\text { heidskenmerken NA en self-efficacy zijn niet van invloed } \\
\text { op arbeidstevredenheid }\end{array}$ & $11 \times$ & ja & nee \\
\hline $\begin{array}{l}\text { Beehr, Glaser, } \\
\text { Canali \&Wall- } \\
\text { wey }(2001)\end{array}$ & $\begin{array}{l}\text { De werkkenmerken zijn van invloed op de } \\
\text { arbeidssatisfactie }\end{array}$ & $7 \times$ & ja & nvt \\
\hline Chaplain (2001) & $\begin{array}{l}\text { Werkkenmerken (Karasek-model) bepalen stress en } \\
\text { tevredenheid }\end{array}$ & $4 \times$ & ja & nvt \\
\hline $\begin{array}{l}\text { Rodriguez, } \\
\text { Bravo, Peiro \& } \\
\text { Schaufeli (2001) }\end{array}$ & $\begin{array}{l}\text { In een longitudinale studie blijkt dat naast de taakken- } \\
\text { merken ook factoren als NA en locus of control een } \\
\text { bijdrage leveren aan arbeidstevredenheid }\end{array}$ & $3 x$ & ja & ja \\
\hline
\end{tabular}

\footnotetext{
* Het aantal citaties is het aantal keren dat de bijdrage is geciteerd in in de Social Sciences Citation Index opgenomen tijdschriften (bepaald op 19-2-06)
}

Relatie tussen werkkenmerken en arbeidstevredenheid

De resultaten in tabel 2 laten zien dat de meningen verdeeld zijn over het feit of de werkkenmerken de arbeidstevredenheid bepalen.

Van de vaakst geciteerde onderzoeken geeft Kalleberg (1977), die ook in tabel 1 staat, aan dat er een sterke relatie is tussen de waargenomen werkkenmerken en de arbeidstevredenheid. Deze relatie is sterker dan die tussen de wensen (values) van medewerkers en arbeidstevredenheid. Het gaat in dit onderzoek echter nadrukkelijk om waargenomen werkkenmerken. Bovendien geeft Kalleberg aan dat andere factoren, zoals ras, werkervaring en arbeidsmarktkansen ook een rol spelen. 'Objectieve' werkkenmerken verdienen volgens Kalleberg nader onderzoek.

In tegenstelling tot Kalleberg (1977) geven de resultaten van het onderzoek van Glisson \& Durick (1988) nadrukkelijk aan dat werkkenmerken wel, en persoonskenmerken niet van invloed zijn op de arbeidstevredenheid. Zij verrichtten onderzoek onder 319 werknemers van 22 verschillende zorginstellingen, om de invloed van de werkkenmerken, persoonskenmerken en organisatiekenmerken te meten op arbeidstevredenheid en betrokkenheid. De resultaten laten zien dat de werkkenmer- ken, gebaseerd op het Job Characteristics Model van Hackman \& Oldham (1980) bepalend zijn voor de arbeidstevredenheid. Vooral rolambiguïteit en afwisseling in het werk (skill variety) zijn van invloed op de arbeidstevredenheid. Persoonskenmerken als leeftijd, geslacht, werkervaring en opleiding blijken geen invloed te hebben op de tevredenheid.

Het onderzoek van Warr (1991) was gericht op het ontwikkelen van een meetinstrument voor welzijn en geestelijke gezondheid in het werk. Met betrekking tot arbeidstevredenheid komt hij op basis van gegevens van 1686 respondenten tot de conclusie dat (intrinsieke) arbeidstevredenheid voor verschillende beroepen samenhangt met twee dimensies van welzijn: de 'bezorgdheid - tevredenheid'dimensie en de 'depressiviteit - enthousiasme'-dimensie. Deze dimensies hangen ook sterk samen met de waargenomen werkkenmerken. Maar in deze relaties spelen persoonskenmerken als leeftijd en geslacht ook een belangrijke rol. De relatie tussen werkkenmerken en tevredenheid is in dit onderzoek dus niet direct onderzocht, maar alleen indirect via de welzijnsdimensies.

Een groot aantal onderzoekers in tabel 2 heeft zich gericht op het toetsen van het Job 
Demand-Control Model van Karasek (1979). Landsbergis (1988) heeft het model getoetst bij 289 medewerkers van verpleeghuizen. Daaruit blijkt dat arbeidsontevredenheid significant hoger is in functies waarin hoge werkdruk is gecombineerd met een gebrek aan regelmogelijkheden. Deze relatie bleef significant bij controle voor leeftijd, geslacht, opleidingsniveau, burgerlijke staat, kinderen, en aantal en aard van werkuren per week. Fox, Dwyer \& Ganster (1993) komen voor een steekproef van 136 verpleegkundigen tot dezelfde conclusie dat lagere arbeidstevredenheid samenhangt met een situatie waarin hoge werkdruk en lage regelmogelijkheden voorkomen. Als toevoeging hierop geven ze aan dat een groot aantal stressvolle gebeurtenissen in het werk (overlijden van patiënten) een negatieve invloed heeft op arbeidstevredenheid, maar dat dit minder geldt als de regelmogelijkheden hoog zijn.

Beehr et al. (2001) hebben het Job DemandControl Model getoetst door middel van vragenlijstonderzoek onder 115 werknemers van een fabriek. De belangrijkste conclusie is dat zowel de job demands als de mate van controle over het werk in belangrijke mate de arbeidstevredenheid bepalen. Zij merken verder nog op dat het concept arbeidstevredenheid niet verward mag worden met psychological strain (psychische spanning). De job demands en control hebben volgens hen een positieve invloed op de arbeidstevredenheid en een negatieve invloed op de psychische spanning.

Soortgelijke onderzoeken zijn gedaan door Tetrick \& LaRocco (1987), Wall et al. (1996), Parkes \& Von Rabenau (1993), Chaplain (2001), en Dwyer \& Ganster (1991). Ook zij hebben met behulp van vragenlijstonderzoek de relatie tussen de taakkenmerken en arbeidstevredenheid bekeken aan de hand van het model van Karasek. Op basis van de conclusie dat de werkkenmerken de arbeidstevredenheid bepalen, dragen deze auteurs suggesties aan om de arbeidstevredenheid te verbeteren en daarmee de kwaliteit van de arbeid te verhogen.

Xie (1996) heeft het model van Karasek in relatie met arbeidstevredenheid getoetst onder 1200 werknemers afkomstig uit vijf verschillende steden in China. Doel van dit onderzoek was vooral om te toetsen of het model ook houdbaar is in een context die qua cultuur en politieke en economische systemen verschilt van de Europese en Noord-Amerikaanse context, waaruit andere onderzoeken vooral afkomstig zijn. Xie komt tot de conclusie dat er ook in China ondersteuning is voor Karasek's model. Ze plaatst wel een kantekening bij het gebruik van Karasek's model als enige determinant van arbeidstevredenheid; er dient rekening gehouden te worden met individuele verschillen en socio-economische verschillen in de Chinese context.

Een opmerkelijk onderzoek, waarin naar bijna alle hierboven genoemde onderzoeken verwezen wordt, is dat van Sargent \& Terry (1998). Ook zij hebben het model van Karasek getoetst in relatie met arbeidstevredenheid, maar nemen hierin tevens het begrip aanpassing mee. Volgens Sargent \& Terry leidt een hoge mate van controle over het werk tot aanpassing, waardoor een hogere arbeidssatisfactie op te merken is. Een werknemer die meer controle heeft over zijn werk, zal makkelijker zijn wensen bijstellen en zich tevreden stellen, omdat hij weet dat hij door een grote mate van controle toch nog grotendeels zelf kan bepalen hoe hij zijn werk uitvoert. Echter, een dergelijke conclusie als die van De Sitter (1994), dat arbeidstevredenheid vanwege deze aanpassing geen goede maat voor kwaliteit van de arbeid is, wordt door Sargent \& Terry niet getrokken. Zij beschouwen arbeidstevredenheid juist wel als een goede maat voor kwaliteit van de arbeid, want op basis van hun bevindingen over de arbeidstevredenheid komen zij met aanbevelingen voor herontwerp om de kwaliteit van de arbeid te verbeteren.

Een ander geluid over de toetsing van het Karasek-model komt van Payne \& Fletcher (1983). Zij toetsten de uitgebreide variant van het model (met social support als modererende variabele) bij 148 leraren en komen tot de conclusie dat de werkkenmerken maar een klein deel van de variantie in allerlei psychische en gezondheidsgevolgen, waaronder arbeidstevredenheid, verklaren. Op basis hiervan trekken ze de conclusie dat er dus blijkbaar nog andere factoren, zoals persoonlijkheidskenmerken (waaronder NA) en omgevingsfactoren buiten het werk, verantwoordelijk moeten zijn voor de psychische en gezondheidstoestand van werknemers. 
In een studie met een heterogene dataset van 3000 medewerkers komen Fletcher \& Jones (1993) tot een vergelijkbare conclusie, namelijk dat werkkenmerken weliswaar van invloed zijn op arbeidstevredenheid, maar dat de verklaarde variantie erg laag is (maximaal 8 procent). Ook zij suggereren, hoewel niet onderzocht, dat persoonlijkheidskenmerken (locus of control) een belangrijke rol spelen in het verklaren van arbeidstevredenheid.

Spector \& O'Connell (1994) hebben wel persoonlijkheidskenmerken (negatieve affectiviteit, locus of control, en type-A-gedrag) in hun onderzoek meegenomen. Zij concluderen dat arbeidstevredenheid correleert met werkkenmerken, maar ook met locus of control. Tot hun eigen verrassing correleert arbeidstevredenheid niet met NA. NA correleert daarentegen wel met de werkkenmerken rolambiguïteit, rolconflict, belemmeringen in het werk, en interpersoonlijke conflicten.

Een andere opvallende studie in tabel 2 is die van Griffin (1991). Op basis van longitudinaal onderzoek onder 526 kasbedienden bij banken komt hij tot de ontdekking dat na een verandering in de taakkenmerken van de kasbedienden de arbeidstevredenheid sterk toenam, maar dat deze na een periode weer naar het oorspronkelijke niveau terugzakte. Dit in tegenstelling tot de waargenomen werkkenmerken, die gedurende de hele onderzoeksperiode het hogere niveau behielden. Dit resultaat is dus in tegenspraak met Vogelaar \& Van der Vlist (1995), zoals in de inleiding besproken. Een andere longitudinale studie (Saks \& Ashforth, 2000) onder 297 afgestudeerden laat zien dat de situationele factoren rolconflict, rolambiguïteit, role overload, en niet-ingeloste verwachtingen significant van invloed zijn op arbeidstevredenheid na vier (64 procent) en tien maanden ( 32 procent). De meegenomen dispositionele persoonlijkheidskenmerken negatieve affectiviteit en self-efficacy voegden daar geen verklaarde variantie aan toe. Dit in tegenstelling tot de longitudinale studie van Rodriguez et al. (2001), waarin NA en locus of control, naast Karasek's taakkenmerken, een significante invloed hebben.

Uit deze studies blijkt dat de relatie tussen werkkenmerken en arbeidstevredenheid niet onomstotelijk is. Als alleen werkkenmerken als voorspellers voor arbeidstevredenheid worden meegenomen, dan is de invloed daarvan sterk en significant, maar als er ook controlevariabelen worden meegenomen, zoals persoons- of persoonlijkheidskenmerken, dan blijken deze vaak ook van invloed. Werkkenmerken bepalen dus wel arbeidstevredenheid (hypothese 2), maar geen van de studies trekt conclusies over de rol van arbeidstevredenheid als maat voor kwaliteit van de arbeid. De meeste onderzoekers die tot de conclusie komen dat werkkenmerken een goede voorspeller zijn voor arbeidstevredenheid geven wel op basis van hun bevindingen suggesties ter verbetering van arbeidstevredenheid en kwaliteit van de arbeid, daarmee suggererend dat tevredenheid een goede maat voor kwaliteit van de arbeid is. Alleen de longitudinale studie van Griffin (1991) leidt tot de veronderstelling dat arbeidstevredenheid niet iets zegt over de werksituatie, want dan zou de tevredenheid in een verbeterde situatie op het hogere niveau moeten blijven.

\section{Invloed van negatieve affectiviteit op de arbeidstevredenheid}

In verschillende studies naar de relatie tussen fit en tevredenheid (5 van de 28 ) en werkkenmerken en tevredenheid (6 van de 23 ) is ook negatieve affectiviteit (NA) meegenomen als variabele. De meeste hiervan zijn hiervoor reeds besproken. Tabel 3 laat zien dat de meeste studies waarin negatieve affectiviteit is meegenomen, aangeven dat dit een grote invloed heeft op arbeidstevredenheid. In de onderzoeken van Spector (1987) en Hinrichs (1972) blijkt NA zelfs de grootste invloed te hebben.

Uit andere studies blijkt dat NA een invloed heeft naast werk- en/of fitkenmerken /Clark et al., 1996; Parkes \& Von Rabenau, 1993; Ilardi et al., 1993; Rodriguez et al., 2001). In deze studies blijken medewerkers met een hoge mate van NA minder tevreden te zijn. Op basis hiervan komen ze tot de conclusie dat arbeidstevredenheidscijfers meer zeggen over de werknemer als persoon, dan over hoe tevreden hij is met zijn werk.

In het onderzoek van Weiss et al. (1999) bleek de invloed van NA op arbeidstevredenheid indirect via gemoedstoestand te lopen. Ook Necowitz \& Roznowski (1994) zijn terughoudend in de conclusie dat persoonlijkheidskenmerken zonder meer een grote invloed hebben. Alleen in een situatie die niet eenduidig nega- 
Arbeidstevredenheid als maat voor kwaliteit van de arbeid

Tabel 3 Overzicht van de empirische studies over de invloed van negatieve affectiviteit op arbeidstevredenheid

\begin{tabular}{lll}
\hline Onderzoek & Bevindingen & Citatie* Invloed NA? \\
\hline Spector (1987) & $\begin{array}{l}\text { Er is een zwakke relatie tussen werkkenmerken en arbeids- } \\
\text { tevredenheid. De relatie tussen NA en arbeidstevredenheid } \\
\text { is veel sterker }\end{array}$ & 88x ja
\end{tabular}

Spector \&

O'Connel (1994)

Zowel werkkenmerken als persoonlijkheidskenmerken

$84 \times \quad$ niet significant correleren met arbeidstevredenheid

Necowitz \&

Uit twee empirische studies (waarvan één experiment) blijkt

$49 \times$

ja

Roznowski (1994) tevredenheid, maar alleen als de werksituatie niet eenduidig negatief is. Met andere woorden, NA is van invloed in een werksituatie waarin er ruimte is voor interpretatie

Clark, Oswald \&

Warr (1996)

George \& Jones (1996)
Ouderen en nieuwkomers op de arbeidsmarkt zijn meer tevreden omdat deze hun verwachtingen bijstellen. Ook NA is van invloed op de arbeidstevredenheid
Ervaringen in het werk worden door vele facetten bepaald. Verloopintentie wordt in deze studie verklaard door (interacties tussen) arbeidstevredenheid, gemoedstoestand en de mate waarin persoonlijke doelen worden bereikt. Hierbij hangt positieve affectiviteit (omgekeerde van NA) significant positief samen met arbeidstevredenheid
Weiss, Nicholas \& Daus (1999)
Naast de beleving van de werksituatie is iemands gemoedstoestand van invloed op arbeidstevredenheid. lemands gemoedstoestand wordt op zijn beurt beïnvloed door de mate van positieve en negatieve affectiviteit

\section{Parkes \& Von}

Rabenau (1993)
Ondersteuning voor het Karasek-model: hoge demands en lage control leiden tot dissatisfactie. Maar daarnaast heeft ook NA invloed op de arbeidstevredenheid

Ilardi, Leone, Kasser $\quad E r$ is een relatie tussen verwachtingen en arbeidstevredenheid,

\& Ryan (1993) en bij discrepantie tussen verwachtingen en werkkenmerken zullen de verwachtingen worden aangepast. Daarnaast blijkt NA van invloed te zijn op arbeidstevredenheid

Saks \& Ashford (2000)
In longitudinaal onderzoek komt naar voren dat de situationele factoren (werkkenmerken) een significante invloed hebben op arbeidstevredenheid. De persoonlijkheidskenmerken NA en self-efficacy zijn niet van invloed op arbeidstevredenheid

\section{$37 \times \quad$ ja}

$20 \times \quad$ ja

ja

Er is sprake van aanpassing, maar ook de persoonskenmerken $7 \times \quad$ ja NA en depressie zijn van invloed op arbeidstevredenheid

Hinrichs (1972)

NA en depressie zijn van inviloed op arbeidstevredenheid

Rodriguez, Bravo, Peiro \& Schaufeli (2001)
Naast de taakkenmerken uit het Karasek-model leveren ook factoren als NA en locus of control een bijdrage aan arbeidstevredenheid

\footnotetext{
* Het aantal citaties is het aantal keren dat de bijdrage is geciteerd in in de Social Sciences Citation Index opgenomen tijdschriften (bepaald op 19-2-06)
} 
tief is, speelt NA een rol in het bepalen van arbeidstevredenheid. Als de situatie negatief is, is ook de arbeidstevredenheid laag. Maar als er ruimte voor interpretatie is, dan is NA hierop van invloed. Necowitz en Roznowski vermoeden dat ook in een situatie die eenduidig positief is, NA geen invloed heeft, maar dat konden ze op basis van hun onderzoek niet aantonen. In slechts twee van de elf onderzoeken waarin NA werd gemeten bleek NA geen significante invloed te hebben. Zoals bij tabel 2 reeds besproken, bleek uit het onderzoek van Spector \& O'Connel (1994) dat NA niet significant correleert met arbeidstevredenheid. Ook in de bij tabel 2 besproken longitudinale studie van Saks \& Ashforth (2000) onder afgestudeerden blijken de meegenomen persoonlijkheidskenmerken self-efficacy en NA niet de verwachte invloed te hebben.

Hoewel het aantal studies waarin NA als variabele is meegenomen beperkt is, blijkt er toch uit dat NA een grote invloed heeft op arbeidstevredenheid. Hieruit kan geconcludeerd worden dat arbeidstevredenheid in ieder geval voor een groot deel tot een persoonlijkheidseigenschap herleid kan worden. Daarmee bevestigen we hypothese 3 .

\section{Conclusie}

Uit de resultaten van ons literatuuronderzoek blijkt dat de discussie over het nut van arbeidstevredenheid als maat voor kwaliteit van de arbeid in de bestudeerde Engelstalige literatuur niet speelt. Wel kunnen we uit de studies die we in dit artikel hebben opgenomen, argumenten afleiden die inzicht geven in het nut van het meten van arbeidstevredenheid als maat voor kwaliteit van de arbeid. We hebben in de inleiding gesteld dat arbeidstevredenheid alleen een goede maat voor kwaliteit van de arbeid kan zijn als het iets zegt over de arbeidssituatie, en niet een maat voor aanpassing is of herleidbaar tot een persoonlijkheidskenmerk.

We hebben uit de gevonden studies niet kunnen concluderen dat er sprake zou zijn van aanpassing (hypothese 1). De belangrijkste reden daarvoor is dat aanpassing als fenomeen niet is gemeten. Daartoe is longitudi- naal onderzoek nodig, en dat is op dit terrein (nog) niet veelvuldig voorhanden. Wel gebruiken veel onderzoekers de term aanpassing om de mate van arbeidstevredenheid bij een misfit te verklaren (bijvoorbeeld Meglino et al., 1989; Bretz \& Judge, 1994).

Bij het toetsen van de tweede hypothese bleek dat veel studies weliswaar aantonen dat werkkenmerken een relatie hebben met arbeidstevredenheid, maar dat deze soms zwak is (Payne \& Fletcher, 1983; Fletcher \& Jones, 1993), of dat ook andere kenmerken daarop van invloed zijn. Dit spreekt het onderzoek van Arvey (1991) tegen die concludeerde dat 40 tot 60 procent van arbeidstevredenheid door werkkenmerken wordt verklaard. Niet alleen negatieve affectiviteit (hypothese 3), maar ook andere persoons- en persoonlijkheidskenmerken zijn naast de werkkenmerken van invloed. Vaak interacteren de werken persoon(lijkheid)skenmerken. Op basis hiervan moeten we concluderen dat het meten van arbeidstevredenheid als maat voor kwaliteit van de arbeid niet voldoet. Aangezien arbeidstevredenheid niet alleen of niet in grote mate afhangt van de werkkenmerken, die door organisaties beïnvloedbaar zijn, is het dus moeilijk op basis van arbeidstevredenheidscijfers de kwaliteit van de arbeid te verbeteren. Om daadwerkelijk de kwaliteit van de arbeid te verbeteren is het echter noodzakelijk ook deze werkkenmerken in kaart te brengen. Een arbeidstevredenheidsonderzoek waarin alleen de tevredenheid wordt gemeten zal onvoldoende aangrijpingspunten opleveren om de kwaliteit van de arbeid te verbeteren. Deze conclusie sluit aan bij De Witte's (2001) aanbeveling om in een zinvolle analyse zowel de 'objectieve' arbeidssituatie als de 'subjectie-

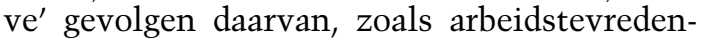
heid, in hun onderlinge samenhang aan bod te laten komen. Echter, aangezien NA (en wellicht nog andere persoonlijkheidskenmerken) een zo grote rol speelt bij arbeidstevredenheid, stellen wij voor om in arbeidstevredenheidsonderzoek in ieder geval een maat voor NA mee te nemen en de relatie tussen werkkenmerken en arbeidstevredenheid te controleren voor de invloed ervan.

Ten slotte blijkt uit onze analyse dat het concept aanpassing nader en nauwkeuriger geoperationaliseerd moet worden. Bij voor- 
keur moeten de relaties in de tijd (longitudinaal) worden getoetst. Dergelijke studies ontbreken vooralsnog en ze kunnen ons inzicht verschaffen in de rol van aanpassing in het ontstaan van arbeidstevredenheid.

\section{Noot}

1 Een zoekopdracht in ISI Web of Science op 14 september 2006 met 'job satisfaction' als trefwoord leverde meer dan 7600 treffers op van bijdragen in tijdschriften die zijn opgenomen in de Social Sciences Citation Index.

\section{Literatuur}

Achterberg, P., D. Houtman, \& B. Jetten (2003). Arbeidstevredenheid: een aanpassingsfenomeen? Tijdschrift voor Arbeidsvraagstukken, 19(3): 214-227.

Arvey, R.D., G.W. Carter, \& D.K. Buerkley (1991). Job satisfaction: Dispositional and situational influences. International Review of Industrial and Organizational Psychology, 6: 359-383.

Baba, V.V., \& M. Jamal (1991). Routinization of job context and job content as related tot employees' quality of working life: A study of Canadian nurses. Journal of Organizational Behavior, 12: 379386.

Beehr T.A., K.M. Glaser, K.G. Canali, \& D.A. Wallwey (2001). Back to basic: Re-examination of Demand-Control Theory of occupational stress. Work et Stress, 15(2): 115-130.

Berting, J., \& L.U. de Sitter (1971). Arbeidssatisfactie. Theorie, methodiek, feiten. Assen: Van Gorcum.

Black, J.S., \& S.J. Ashford (1995). Fitting In or Making Jobs Fit: Factors Affecting Mode of Adjustment for New Hires. Human Relations, 48(4): $421-437$.

Boxx, W.R., R.Y. Odom, \& M.G. Dunn (1991). Organizational Values and value congruency and their impact on satisfaction, commitment and cohesion: An empirical examination within the public sector. Public Personnel Management, 20(1): 195-205.

Bretz R.D. Jr., \& T.A. Judge (1994). Person-Organization Fit and the Theory of Work Adjustment: Implications for Satisfaction, Tenure and Career Succes. Journal of Vocational Behavior, 44(1): 32 54.

Buckley, M.R., D.B. Fedor, J.G. Veres, D.S. Weise, \& S.M. Carraher (1998). Investigating Newcomer Expectations and Job-Related Outcomes. Journal of Applied Psychology, 83(3): 452-461.
Burke, M.J., A.P. Brief, \& J.M. George (1993). The role of negative affectivity in understanding relations between self-reports of stressors and strains: a comment on the applied psychology literature. Journal of Applied Psychology, 78: 402-412.

Büssing A., T. Bissels, V. Fuchs, \& K.M. Perrar (1999). A Dynamic Model of Work Satisfaction: Qualitative Approaches. Human Relations, 52(8): 999-1028.

Cable D.M., \& T.A. Judge (1996). Person-organization fit, job choice decisions, and organizational entry. Organizational Behavior and Human Decision Process, 67(3): 294-311.

Chaplain, R.P. (2001). Stress and Job Satisfaction among Primary Headteachers. Educational Management Administration e) Leadership, 29(2): 197-215.

Christis, J. (1998). Arbeid, Organisatie en stress. Een visie vanuit de sociotechnische arbeids-en organisatiekunde. Amsterdam: Het Spinhuis.

Clark, A., A. Oswald, \& P. Warr (1996). Is job satisfaction U-shaped in age? Journal of Occupational and Organizational Psychology, 69: 5781.

Dawis R.V., \& L.H. Lofquist (1978). A note on the dynamics of work adjustment. Journal of Vocational Behavior, 12: 76-79.

Dawis, R.V., \& L.H. Lofquist (1984). A psychological theory of work adjustment: an indvidual-diffrences Model and its Applications. Minneapolis, University of Minnesota Press.

Dwyer, D.J., \& D.C. Ganster (1991). The effects of job demands and control on employee attendance and satisfaction. Journal of Organizational Behavior, 12: 595-608.

Edwards, J.R., R.D. Caplan, \& R. Van Harisson (1998). Person-Environment fit theory. In C.L. Cooper, Theories of organizational stress (pp. 2867). Oxford: Oxford University Press.

Edwards, J.R., \& N.P. Rothbard (1999). Work and Family Stress and Well-Being: An Examination of Person-Environment Fit in the Work and Family Domains. Organizational Behavior and Human Decision Processes, 77(2): 85-129.

Eggerth, D.E. (2004). Applying the Bradley-TerryLuce method to P-E fit. Journal of Vocational Behavior, 64: 92-107.

Festinger, L. (1957). A Theory of Cognitive Dissonance. London: Travistock Publications, 1-47.

Fletcher B.C., \& F. Jones (1993). A Refutation of Karasek's Demand-Discretion Model of Occupational Stress with a Range of Dependent Measures. Journal of Organizational Behavior, 14(4): 319-330.

Fox M.L., D.J. Dwyer, \& D.C. Ganster (1993). Effects of stressful job demands and control on psychological and attitudinal outcomes in a hospital setting. Academy of Management Journal, 36(2): 289-318. 
Furnham, A. (1992). Personality at work: The role of individual differences in the workplace. London/New York: Routledge.

Garland T.N., N. Oyabu, \& G.A. Gipson (1989). Job satisfaction among nurse assistants employed in nursing homes: An analysis of selected job characteristics. Journal of Aging Studies, 3(4): 369389.

Geelhoed, J., H. van der Loo, \& S. Samhoud (2003). Plezier et prestatie. Hét managementprincipe voor organisaties. Den Haag: Academic Service.

George, J.M., \& G.R. Jones (1996). The Experience of Work and Turnover Intensions: Interactive Effects of Value Attainment, Job Satisfaction and Positive Mood. Journal of Applied Psychology, 81(3): 318-325.

Glisson C., \& M. Durick (1988). Predictors of Job Satisfaction and Organizational Commitment in Human Service Organizations. Administrative Science Quarterly, 33(1): 61-81.

Gottfredson, G.D., \& J.L. Holland (1990). A Longitudinal Test of the Influence of Congruence: Job Satisfaction, Competency Utilization and Counterproductive Behavior. Journal of Counseling Psychology, 37(4): 389-398.

Green, F., \& N. Tsitsianis (2005). An Investigation of National Trends in Job Satisfaction in Brittain and Germany. British Journal of Industrial Relations, 43(3): 401-429.

Griffin, R.W. (1991). Effects of Work Redesign on Employee Perceptions, Attitudes and Behaviors: A Long-Term Investigation. Academy of Management Journal, 34(2): 425-435.

Hackman, J.R., \& G.R. Oldham (1976). Motivation through the design of work: A test of a theory. Organizational Behavior \& Human Performance, 16: 250-279.

Hackman, J.R., \& G.R. Oldham (1980). Work redesign. Philippines: Addison-Wesley.

Hesketh B., \& D. Gardner (1993). PersonEnvironment Fit Models: A Reconceptualization and Empirical Test. Journal of Vocational Behavior, 42(3): 315-322.

Heskett, J.J., T.O. Jones, G.W. Loveman, W.W. Sasser, \& S. Schlesinger (1994). Putting the Service-Profit Chain to work. Harvard Business Review, 72(2): 164-174.

Hinrichs, J.R. (1972). Value adaptation of new $\mathrm{PhD}$ 's to academic and industrial environments. A comparative longitudinal study. Personnel Psychology, 25: 545-565.

Hulin C.L., \& P.C. Smith (1965). A Linear Model of Job Satisfaction. Journal of Applied Psychology, 49(3): 209-216.

Iaffaldano, M.T., \& P.M. Muchinsky (1985). Job Satisfaction and Job performance: A MetaAnalysis. Psychological Bulletin, 97(2): 251-273.
Ilardi, B.C., D. Leone, T. Kasser \& R.M. Ryan (1993). Employee and Supervisor Ratings of Motivation: Main Effects and Discrepancies Associated with Job Satisfaction and Adjustment in a Factory Setting. Journal of Applied Social Psychology, 23: 1789-1805.

Janson, P., \& J.K. Martin (1982). Job Satisfaction and age: A test of two views. Social Forces, 60: 1089-1102.

Judge, T.A., S. Parker, A.E. Colbert, D. Heller \& R. Ilies (2001). Job Satisfaction: A Cross-Cultural Review. In N. Anderson, D.S. Ones, H.K. Sinangil, \& C. Viswesvaran (eds.). Handbook of Industrial, Work and Organizational Psychology. Volume 2: Organizational Psychology (pp. 25-52). London, etc.: SAGE Publications.

Kalleberg A.L. (1977). Work Values and Job Rewards: A Theory of Job Satisfaction. American Sociological Review, 42(1): 124-143.

Kalleberg A.L., \& K.A. Loscocco (1983). Aging, Values and Rewards: Explaining Age Differences in Job Satisfaction. American Sociological Review, 48(1): 78-90.

Karasek, R.A. (1979). Job demands, Job decision latitude, and implications for job redesign. Administrative Science Quarterly, 24(2): 285306.

Landsbergis, P.A. (1988). Occupational Stress Among Health Care Workers: A Test of the Demands - Control Model. Journal of Organizational Behavior, 9(3): 217-239.

Lauver, K.J., \& A. Kristof-Brown (2001). Distinguishing between Employees' Perceptions of Person-Job and Person-Organization Fit. Journal of Vocational Behavior, 59: 454-470.

Lawson, L. (1993). Theory of Work Adjustment personality constructs. Journal of Vocational Behavior, 43: 46-57.

Lipsey, M.W., \& D.B. Wilson (2001). Practical meta-analysis. Thousand Oaks, etc.: Sage Publications.

Looke, E.A. (1976). The nature and causes of job satisfaction. In M.D. Dunnette (ed.). Handbook of industrial and organizational psychology. (pp. 1297-1349) Chicago: Rand McNally.

Meglino, B.M., E.C. Ravlin, \& C.L. Adkins (1989). A work values approach to corporate culture: A field test of the values congruence process and its relationship to individual outcomes. Journal of Applied Psychology, 74(3): 424-432.

Necowitz, L.B., \& M. Roznowski (1994). Negative Affectivity and Job Satisfaction: Cognitive Processes Underlying the Relationship and Effects on Employee behaviors. Journal of Vocational Behavior, 45: 270-294.

O'Reilly C.A., J. Chatman, \& D.F. Caldwell (1991). People and Organizational Culture: A Profile Comparison Approach tot Assessing PersonOrganization fit. Academy of Management Journal, 34(3): 487-516. 
Parkes, K.R., \& C. von Rabenau (1993). Work Characteristics and well-being among psychiatric health-care staff. Journal of Community $\leftrightarrow$ Applied Social Psychology, 3(4): 243-259.

Payne, R., \& B. Fletcher (1983). Job demands, supports and constraints as predictors of psychological strain among school teachers. Journal of Vocational Behavior, 22: 136-147.

Rhodes, S.R., \& M. Doering (1983). An Integrated Model of Career Change. Academy of Management Review, 8(4): 631-639.

Rice, R.W., D.E. Bennett \& D.B. McFarlin (1989). Standards of Comparison and Job Satisfaction. Journal of Applied Psychology, 7(4): 591-598.

Rodriguez, I., M.J. Bravo, J.M. Peiro \& W. Schaufeli (2001). The demands-control-support model, locus of control and job dissatisfaction: A longitudinal study. Work $\oplus$ Stress, 15(2): 97-114.

Rucci, A.J., S.P. Kirn, \& R.T. Quinn (1998). The employee-customer profit chain at Sears. Harvard Business Review, 76(1): 83-97.

Saks, A.M., \& B.E. Ashforth (2000). The role of dispositions, entry stressors, and behavioral plasticity theory in predicting newcomers' adjustment to work. Journal of Organizational Behavior, 21: 43-62.

Saks, A.M., \& B.E. Ashforth (2002). Is job search related to employment quality? It all depends on the fit. Journal of Applied Psychology, 87: 64665.

Sargent, L.D., \& J.D. Terry (1998). The effects of work control and job demands on employee adjustment and work performance. Journal of Occupational and Organizational Psychology, 71: 219-236.

Semmer N., \& U. Schallberger (1996). Selection, Socialization and Mutual Adaption: Resolving Discrepancies Between People and Work. Applied Psychology, 45(3): 263-288.

Sitter, L.U. de (1994). Synergetisch produceren. Human Resources Mobilisation in de produktie: een inleiding in structuurbouw. Assen: Van Gorcum.

Spector, P.E. (1987). The interactive effect of perceived control and job stressors on affective reactions and health outcomes for clerical workers. Work e Stress, 1: 155-162.

Spector, P.E., S. Fox, \& P.T. Van Katwyk (1999). The role of negative affectivity in employee reactions to job characteristics: Bias effect or substantive effect? Journal of Occupational and Organizational Psychology, 72: 205-218.

Spector, P.E., \& B.J. O'Connel (1994). The contribution of personality traits, negative affectivity, locus of control and Type A to the subsequent reports of job stressors and job strains. Journal of Occupational and Organizational Psychology, 67: 1-11.

Staines, G.L., \& P.R. Quinn (1979). American Workers Evaluate the Quality of Their Jobs. Monthly Labor Review, 102(1): 3-12.
Staw, B.M., \& J. Ross (1985). Stability in the Midst of Change: Dispositional Approach to Job Attitudes. Journal of Applied Psychology, 70(3): 469-481.

Taris, R. (2003). Person-environment fit: a longitudinal study of the interaction between employee characteristics and work environmental characteristics. Amsterdam: Vrije Universiteit.

Tetrick, L.E., \& J.M. LaRocco (1987). Understanding, Prediction, and Control as Moderators of the Relationships Between Perceived Stress, Satisfaction and Psychological Well-Being. Journal of Applied Psychology, 72(4): 538-543.

Vogelaar, A., \& R. van der Vlist (1995). Het Job Characteristics Model en taakherontwerp. Gedrag en Organisatie, 8(2): 65-87.

Wall, T.D., P.R. Jackson, K.S. Mullar, \& S.K. Parker (1996). The Demand-Control Model of strain: a more specific test. Journal of Occupational and Organizational Psychology, 69: 153-166.

Warr, P. (1990). The measurement of well-being and other aspects of mental health. Journal of Occupational Psychology, 63(3): 193-210.

Weiss, H.M., J.P. Nicholas \& C.S. Daus (1999). An examination of the joint effects of affective Experiences and job Beliefs on Job Satisfaction and variations in Affective Experiences over time. Organizational Behavior and Human Decision Processes, 78: 1-24.

Witte, H. de, (2001). Arbeidstevredenheid: een zinvol concept? Over.Werk. Tijdschrift van het Steunpunt WAV, 11(4): 18-21.

Witte, M. de \& J. Van Ruysseveldt (1998). Oordelen over 'kwaliteit van de arbeid': hedendaagse stromingen. In J. Van Ruysseveldt, M. de Witte, \& J. von Grumbkow (red.). Organiseren van mens en arbeid. Hedendaagse benaderingen van kwaliteit van de arbeid (pp. 11-37). Heerlen: Open Universiteit.

Wright, J.D., \& R.F. Hamilton (1978). Work satisfaction and Age: Some evidence for the 'Job Change' Hypothesis. Social Forces, 56(4): 11401158.

Xie, J.L. (1996). Karasek's Model in the People's Republic of China: Effects of Job Demands, Control, and Individual Differences. The Academy of Management Journal, 39(6): 15941618. 